tions, what insights can we glean about democracy by answering them? While the students addressed some of these questions, they had too little time to address others. The time limits that we faced always loomed rather large, making it more likely that we would shunt the design and process evaluations aside in the interests of squeezing in another model of democracy or another student presentation. This suggests that the course would work better as a two-semester offering.

Finally, this and other courses need not be democratized as completely as I did in this experiment. Educational practices can be partly democratized, consonant with time constraints, the subject matter, and the level of willingness and preparation of students. While it is clear that students in this course were both willing and able to shoulder more responsibility for their own learning, the shift from my shoulders to theirs need not be as extensive as it was in this course.

\section{Notes}

1. I would like to thank the students and colleagues who participated in and critically evaluated this experiment in democratic education for their commitment, enthusiasm, patience, good humor, creativity, and critical commentary on the course.

2. See Paolo Freire (1990). Alternatively, John Dewey used the metaphors of studentas-cistern into which the instructor pours knowledge; student-as-blank phonograph onto which the instructor etches knowledge; and student-as-sponge who soaks up the knowledge provided by the instructor (see Boydston 1990).

3. In order to jumpstart the course, I ordered three books before the semester. These were David Held, Models of Democracy (1987); Paolo Freire, Pedagogy of the Oppressed (1990); and C. B. Macpherson, The Life and Times of Liberal Democracy (1977). I also assigned John Dewey's essay entitled "The Need for a Philosophy of Education" (1934).

4. It is possible that the students who responded incorrectly to these questions did so not because they misunderstood the points but because, for ideological or other reasons, they simply refused to accept them as valid. Most of these students were reared in ideologically conservative and libertarian Orange County, and at least some tend to embrace their political beliefs rather uncritically.

\title{
Teaching Iran-Contra: Further Reflections
}

\section{Ronald H. Chilcote, University of California-Riverside}

My brief essay departs from the useful discussion by John Scott Masker on his experience teaching the Iran-Contra affair which appeared in PS (1996, 701-03). Masker incorporated a six-week unit in a semester course on U.S. foreign policy, whereas I have incorporated the Iran-Contra scandal into both quarter and semester courses on the U.S. and Latin American relations. Thus, there are similarities and differences in our approaches to this theme.

Our approaches run somewhat parallel in our recognition of the significance of the scandal for studying, understanding, and gaining insights into the formulation, manipulation, and practice of U.S. foreign policy along with permitting discussion of presidential leadership styles, congressional inquiry, congressional- executive tensions, bureaucratic politics, and public reaction and opinion. We agree that testimonials and memoirs by many of the principal participants in the affair constitute an extraordinary source of material, and we have had to refine the mass of information on the subject in order to facilitate and motivate students in the busy task of making sense of the mostly covert activities. We also have grappled with how to involve students in serious thinking about implications and moving toward some analysis of the complex case. Our classroom experiences have led us away from standard lecture and discussion formats and toward a pedagogy that emphasizes frequent writing tasks, student choice in readings, video tapes of the congressional hearings, and

\section{References}

Boydston, Jo Ann, ed. 1990. John Dewey: The Later Works, 1925-1953. Vol. 9. Carbondale, IL: Southern Illinois University Press.

Freire, Paolo. 1990. Pedagogy of the Oppressed. New York: Continuum.

Held, David. 1987. Models for Democracy. Stanford: Stanford University Press.

Macpherson, C. B. 1977. The Life and Times of Liberal Democracy. Oxford: Oxford University Press.

\section{About the Author \\ Mark Mattern is as- sistant professor of political science at Chapman University. $\mathrm{He}$ is the author of Acting in Concert: $\mathrm{Mu}$ - sic, Community and Political Action (Rut- gers University Press, 1998). His current research interests in- clude John Dewey's work on art, and workplace democracy in the Minnesota "new wave" cooperatives.

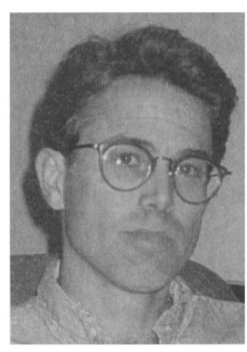

group discussion and problem-solving with frequent shifting between full class and small group activity. In short, our methods include case study, student-centered cooperative learning, and individual writing on many tasks. Whatever our relative successes in the classroom, I suspect that Masker would agree with my emphasis on encouraging basic skills such as writing, articulate speaking, synthesizing diverse material, critical thinking, and analyzing.

Our differences in approach are both substantive and pedagogical. I build the Iran-Contra case out of a general overview to U.S. foreign policy in Latin America, beginning with the Monroe Doctrine of 1823, touching upon Manifest Destiny during the 19th century, and progressing through the Good Neighbor Policy 
under Franklin Delano Roosevelt up to the Cold War period. This sets a context in which to examine hundreds of cases of U.S. intervention, mostly in the Caribbean, Central America, and Mexico, but in particular post-World War II cases of foreign involvement and domestic response in the Panama Canal Zone (1903-1978), Guatemala (1954), Cuba (1961 and 1962), Brazil (1964), Dominican Republic (1965), Chile (1973), Falklands-Malvinas (1982), Grenada (1983), and Panama (1989). Three types of intervention are emphasized: overt, such as in the Dominican Republic and Panama; covert, as in Guatemala and Chile; and corporate, conspicuous examples being United Fruit Company in Guatemala, Hanna Mining in Brazil, and Anaconda and Kennecott in Chile.

A Latin American perspective on this history of intervention can be gleaned from Arévalo (1961) and Galeano (1973); contrasting debate in Fagen and Cotler (1974); and critical overviews in Burbach and Flynn (1983), Landau (1988) and Pearce (1981). A particular challenge is uncovering covert activities in the area, but students quickly grasp them through autobiographical exposés by former Central Intelligence Agency operatives such as Agee (1975), Marchetti and Marks (1980); while journalistic accounts are in Blum (1986), Wise (1992), and Woodward (1987); and academic analyzes by Chomsky (1988), Berman and Halperin, eds. (1975), Klare and Kornbluh (1988), and Treverton (1987) are instructive. The issue of drugs has particular relevance to the covert actions, as emphasized in McCoy (1990) and brought out in 1987 and 1988 in hearings led by Senator John Kerry and his Senate Subcommittee on Narcotics, Terror, and International Relations.

The Iran-Contra case must be studied in light of the general crisis in Central America and the continuing U.S. presence in the area after the Sandinista revolutionaries came to power in 1979. This crisis is depicted in Chomsky (1988), Drisken, ed. (1983), and McClintock (1985). The major memoirs of participants in Iran-Contra identified by Masker could be supplemented by the testi- mony before the congressional panels (U.S. House, 1987) and writings by Oliver North $(1987,1991)$, along with Bradlee, Jr's (1985) portrayal of North's rise and fall. Congressional testimony is available in audio and video format, although my own effort involved taping the hearings and preparing an index of their content. The 43 video tapes, comprising more than 200 hours of testimony, and the index are archived in the media library at the University of CaliforniaRiverside, and are available for research by students. My personal archive also contains close to a hundred documentary video tapes of various cases of intervention, the majority on Central America and Iran-Contra; these tapes are interspersed throughout my course. Another major resource available to students through the UC-Riverside library is my ten-volume archive of the major newspaper clippings about Iran-Contra, compiled principally from the Los Angeles Times and the New York Times during the period 1983 to present. One of the volumes comprises special topic analysis in periodicals such as The Nation, New Republic, Mother Jones, and $Z$ Magazine. Another volume focuses on news analysis of congressional aid to the contras, while a third looks at the role of drug trafficking and funding of clandestine activities in Central America. A summary of events is in National Security Archive (1987) and the Facts on File chronology organized by Trager (1988).

The Iran-Contra case can be studied from many angles and sources not mentioned or elaborated by Tasker, who emphasizes conservative and moderate perspectives. I encourage students to explore all perspectives and to prepare term papers on the Iran-Contra case. Their focus might be on the workings of the National Security Council, the privategovernment operations, congressional infighting, the Iranian hostage situation and its impact on the Carter and Reagan presidencies, or U.S. covert and direct support for the counterrevolutionaries opposed to the Sandinistas and such activities' impact on internal Nicaraguan politics. Students might be drawn in and enticed by the many liberal-pro- gressive and leftist analyses and interpretations of the contra war and clandestine U.S. activities, such as Emerson (1988), Gutman (1988), Graubard (1992), Kornbluh and Byrne, eds. (1993), Marshall, Scott, and Hunter (1987), or Parry and Kornbluh (1988). An assassination attempt against contra leader Eden Pastora resulted in the death and injury of several journalists, prompting the Christic Institute to allege a conspiracy in a lawsuit filed against the federal government. Moyers (1988) characterized this incident as a constitutional crisis provoked by "a secret government." Investigations into such incidents brought new details to the surface (see Avigan and Honey 1987; Sheehan 1987; Sheehan and Ortega 1987; and Siegel 1988). The Iranian connection is brought out in Segev (1988), while Sick (1992) and Waas and Unger (1992) deal with the "October Surprise" involving George Bush and CIA director William Casey in the years of the Regan administration, and Mayer and McManus (1988) expose the "unmaking" of the Reagan Presidency.

I encourage students to research deeply into a topic of their choice, to find positions on the perplexing issues, and to back those positions up with reference to the wealth of information available. The emphasis on seeking a critical stance helps students realize that all questions raised by the Iran-Contra events have not been answered and that there is much to do. While exposure to the lies and deceit, the secret dealings and covert activities, and political influences, so conspicuous in this case study, may lead to dismay and even disillusionment about American politics and practices, in the long r un, I believe it also builds student confidence, strengthens individual judgment and conviction, leads to critical thinking, and shows students way of transcending complex politics and eventually gaining a true understanding of the nature of American democracy. 


\section{References}

Agee, Philip. 1975. Inside the Company: CLA Diary. Harmondsworth: Penguin Books.

Arévalo, Juan José. 1961. The Shark and the Sardines. New York: Lyle Stuart.

Avirgan, Tony, and Martha Honey. 1987. La Penca: On Trial in Costa Rica. The CIA vs. the Press. San Jose: Editorial Porvenir.

Berman, Jerry I., and Morton H. Halperin, eds. 1975. The Abuses of the Intelligence Agencies. Washington, DC: Center for $\mathrm{Na}$ tional Security Studies.

Blum, William. 1986. The CIA: A Forgotten History. London: Zed Press.

Bradlee, Jr, Ben. 1988. Guts and Glory: The Rise and Fall of Oliver North. New York: Donald I. Fine.

Burbach, Roger, and Patricia Flynn, eds. 1984. The Politics of Intervention: The United States in Central America. New York: Monthly Review.

Chomsky, Noam. 1985. Tuming the Tide: U.S. Intervention in Central America and the Struggles for Peace. Boston: South End Press.

- 1988. The Culture of Terrorism. Boston: South End Press.

Colodny, Len, and Robert Gettlin. 1991. Silent Coup: The Removal of a President. New York: St Martins.

Driskin, Martin, ed. 1983. Trouble in our Backyard: Central America and the United States in the Eighties. New York: Pantheon.

Emerson, Steven. 1988. Secret Warriors: Inside the Covert Military Operations of the Reagan Era. New York: Putnam's Sons.

Fagen, Richard R., and Julio Cotler. 1974. Latin America and the United States. Stanford: Stanford University Press.

Galeano, Eduardo. 1973. Open Veins of Latin America. New York: Monthly Review Press.

Garza, Hedda. 1995. The Watergate Investigation Index, 2 vols. Wilmington, DE: Scholarly Resources.

Graubard, Stephen R. 1992. Mr. Bush's War: Adventures in the Politics of Illusion. New York: Hill and Wang.

Gutman, Roy. 1988. Banana Diplomacy: The Making of American Policy in Nicaragua,
1981-1987. New York: Simon and Schuster.

Klare, Michael T., and Peter Kornbluh. 1988. Low Intensity Warfare: Counterinsurgency, Proinsurgency, and Antiterrorism in the Eighties. New York: Pantheon.

Kornbluh, Peter, and Malcolm Byrne, eds. 1993. The Iran-Contra Scandal: The Declassified History. New York: New Press.

Landau, Saul. 1988. The Dangerous Doctrine, National Security and U.S. Foreign Policy. Boulder, CO: Westview Press.

Marchetti, Victor, and John D. Marks. 1980. The CIA and the Cult of Intelligence. New York: Dell Publishing.

Marshall, Jonathan, Peter Dale Scott, and Jane Hunter. 1987. The Iran-Contra Connection: Secret Teams and Covert Operations in the Reagan Era. Boston: South End Press.

Martin, David C., and John Walcott. 1988. Best Laid Plans: The Inside Story of America's War Against Terrorism. New York: Harper and Row.

Mayer, Jane, and Doyle McManus. 1988. Landslide: The Unmaking of the President, 1984-1988. New York: Houghton Mifflin.

McClintock, Michael. 1985. The American Connection. Vols I and II. London: Zed Press.

McCoy, Alfred W. 1990. Heroin: CLA Complicity in the Global Drug Trade. New York: Lawrence Hill. Revised Ed.

Moyers, Bill. 1988. The Secret Government: The Constitution in Crisis. Cabin John, MD: Seven Locks Press.

National Security Archive. 1987. The Chronol ogy: The Documented Day-by-Day Account of the Secret Military Assistance to Iran and the Contras. New York: Warner Books.

New York Times Special Report of the Congressional Committees Investigating the IranContra Affair. 1987. New York: Times Books.

North, Oliver L. 1987. Taking the Stand. New York: Pocket Books.

. 1991. Under Fire: An American Story. New York: Harper Collins.

Parry, Robert, and Peter Kornbluh. 1988. "Iran-Contra's Untold Story." Foreign Policy 72(Fall): 3-30.

Pearce, Jenny. 1981. Under the Eagle. Boston: South End Press.
Segev, Samuel. 1988. The Iranian Triangle: The Untold Story of Israel's Role in the Iran-Contra Affair. New York: Free Press.

Sheehan, Daniel 1987. "Affidavit Outlining Evidence of a Criminal Conspiracy to Support the Contra War." Washington, DC: Christic Institute.

_ sault on Nicaragua: The Untold Story of the U.S. "Secret War". San Francisco: Walnut Publishing.

Sick, Gary. 1991. October Surprise. America's Hostages in Iran and the Election of Ronald Reagan. New York: Times Books.

Siegel, Daniel. 1988. "Iran/Contra Network Faces Trial," Convergence (Spring), $1 \mathrm{ff}$.

Trager, Oliver, ed. 1988. The Iran-Contra Arms Scandal: Foreign Policy Disaster. New York: Facts on File Publications.

Treverton, Gregory F. 1987. Covert Action: The Limits of Intervention in the Postwar Period. New York: Basic Books.

U.S. House of Representatives. 1987. Select Committee to Investigate Covert Arms Transactions with Iran and the Nicaraguan Opposition and U.S. Senate Select Committee on Secret ... Report of the Congressional Committees Investigating the IranContra Affair, Washington, D.C.

Waas, Murray, and Craig Unger. 1992. "In the Loop: Bush's Secret Mission," New Yorker, 2 November: 64-83.

Wise, David. 1992. Molehunt: The Secret Search for the Traitors that Shattered the $C L A$. New York: Random House.

Woodword, Bob. 1987. Veil: The Secret Wars of the CIA, 1981-1987. New York: Simon and Schuster.

\section{About the Author}

Ronald H. Chilcote is professor of political science and economics at the University of California-Riverside. He is the author of Power and the Ruling Classes in Northeast Brazil (1990) and Theories of Comparative Politics: The Search for a Paradigm Revisited (1994). 